\title{
Association of inflammatory markers with severity of disease and mortality in COVID-19 patients: a systematic review and meta-analysis
}

Sara Khan ${ }^{\mathrm{a}^{*}}$, Pinki Mishra ${ }^{\mathrm{a}^{*}}$, Rizwana Parveen ${ }^{\mathrm{a}}$, Ram Bajpai ${ }^{\mathrm{b}}$, Mohd Ashif Khan ${ }^{\mathrm{a}}$, Nidhi Bharal Agarwal $^{\mathrm{a}}$

${ }^{\mathrm{a} C e n t r e}$ for Translational and Clinical Research, School of Chemical \& Life Sciences, Jamia Hamdard, New Delhi-110062, India.

${ }^{\mathrm{b}}$ School of Medicine, Keele University, Staffordshire, UK

*These authors contributed equally to the work.

Running Title: Inflammatory markers and COVID-19

\section{Corresponding author}

Nidhi Bharal Agarwal

Centre for Translational and Clinical Research

School of Chemical \& Life Sciences

Jamia Hamdard

New Delhi-110062, India

Phone: $+91-9818334770$

E-mail address: nidhi.bharal@gmail.com

Orcid ID: https://orcid.org/0000-0002-2509-3026 


\title{
Association of inflammatory markers with severity of disease and mortality in COVID-19 patients: a systematic review and meta-analysis
}

\begin{abstract}
Purpose: Literature suggests association of inflammatory markers with the severity and mortality related to COVID19 , but there are varying conclusions available. We aimed to provide an overview of the association of inflammatory markers with the severity and mortality of COVID-19 patients.
\end{abstract}

Methods: We searched Medline (via PubMed), Cochrane, Clinicaltrials.gov databases until Sept 1, 2020.

Results: A total of 21 studies comprising 4023 patients with COVID-19 were included in our analysis. Levels of IL$6(\mathrm{WMD}=18.1795 \% \mathrm{CI} 3.38$ to $32.96, \mathrm{p}=0.016), \mathrm{IL}-8$ (WMD=12.09 95\%CI 4.41 to $19.77, \mathrm{p}=0.002), \mathrm{MCP}-1$ (WMD=146.66 95\%CI 88.16 to 205.16, p<0.001), CRP (WMD=31.09 95\%CI 10.08 to 52.10, $\mathrm{p}=0.004), \mathrm{PCT}$ $(\mathrm{WMD}=-31.2395 \% \mathrm{CI}-37.70$ to $-24.76, \mathrm{p}<0.001), \mathrm{IL}-2 \mathrm{R}(\mathrm{WMD}=861.9395 \% \mathrm{CI} 275.45$ to $1448.41, \mathrm{p}=0.004)$, ferritin (WMD= 1083.34 95\%CI 431.99 to $1734.70, \mathrm{p}=0.001)$ were found significantly higher in the severe group compared with the non-severe group of COVID-19 patients. Moreover, non-survivors had a higher levels of IL-2R $(\mathrm{WMD}=-666.06$ 95\%CI -782.54 to $-549.59, \mathrm{p}<0.001), \mathrm{IL}-8(\mathrm{WMD}=-26.6395 \% \mathrm{CI}-33.031$ to $-20.236, \mathrm{p}<0.001)$, $\mathrm{IL}-10(\mathrm{WMD}=-7.6095 \% \mathrm{CI}-8.93$ to $-6.26, \mathrm{p}<0.001), \mathrm{TNF}-\alpha(\mathrm{WMD}=-4.6095 \% \mathrm{CI}-5.71$ to $-3.48, \mathrm{p}<0.001), \mathrm{IL}-1 \beta$ (WMD=22.66 95\%CI 8.13 to 37.19, $\mathrm{p}=0.002)$, CRP (WMD $=-96.4095 \% \mathrm{CI}-117.84$ to $-74.97, \mathrm{p}<0.001$ ), and ferritin $(\mathrm{WMD}=-937.6095 \% \mathrm{CI}-1084.15$ to $-791.065, \mathrm{p}<0.001)$ when compared to the non-survivor group.

Conclusion: This meta-analysis highlights the association of inflammatory markers with the severity and mortality of COVID-19 patients. Measurement of these inflammatory markers may assist clinicians to monitor and evaluate the severity and prognosis of COVID-19 thereby reducing the mortality rate.

Keywords: inflammatory markers, cytokine storm, interleukin, disease severity, COVID-19

\section{INTRODUCTION}

In December 2019, a largely enveloped virus was labeled as COVID-19, which was discovered in Wuhan, China, rapidly spread globally. It was found out to be a new infectious disease classified under SARS-CoV and MERS$\mathrm{CoV}$ which primarily causes respiratory tract infection ${ }^{1}$. WHO declared the pandemic outbreak of novel 
coronavirus (2019-nCoV) as a global health emergency. As of September 1, 2020 over 216 countries have been affected by the COVID -19 disease with more than Twenty Four million (24,257,989) confirmed cases leading to over $8,27,246$ deaths ${ }^{2}$.

Although, most cases are mild to moderate, some patients develop severe symptoms characterized by respiratory dysfunction and/or multiple organ failure ${ }^{3,4}$. Identification of progression of COVID-19 in the current state, depends mostly on the clinical manifestation. It has been recommended that one of the possible mechanisms of ultimate speedy disease progression is cytokine storm ${ }^{5,6}$. Cytokine storm, also known as cytokine cascade, or hypercytokinemia, is caused by infection, drugs or autoimmune diseases of the body's excessive immunity response 7 . This inflammatory response is associated with elevated levels of inflammatory cytokines and leads to alveolar damage and acute respiratory distress syndrome (ARDS) ${ }^{5}$. Accumulating evidence suggest that an elevated level of inflammatory cytokines is associated with a high severity and case fatality of COVID-19 infection ${ }^{4,6,8-10}$.

Pathological manifestations of COVID-19 greatly resemble what has been seen in SARS and MERS infection where massive interstitial inflammatory infiltrates diffuse in the lung ${ }^{10}$. The main effect of interleukins is to suppress inflammation, however, it has been shown that the over-production of specific inflammatory cytokines such as IL-2, IL-4, IL-6, IL-8, IL-10, tumor necrosis factor (TNF- $\alpha$ ) are the gold standard of viral infection ${ }^{11-13}$. Interleukins can be of high interest for reaching out the target of immunosuppressive therapy approaches by cytokine blockers in COVID-19 like several approaches, including global targeting of the inflammation or neutralizing a single key inflammatory mediator, can be employed to cope with cytokine storm ${ }^{14}$. Interleukins promotes specific differentiation of $\mathrm{CD}^{+} / \mathrm{CD}^{+}$Tcells, thus performing an important function in the linking of innate to acquired immune response. Also, in combination with transforming growth factor (TGF)- $\beta$, interleukins are indispensable for Th17 differentiation from nave $\mathrm{CD}^{+}{ }^{\mathrm{T}}$ cells ${ }^{15}$. Elevated levels of IL-6 can cause hyper-activation of JAK/STAT3 signaling, which is often associated with poor patient outcomes ${ }^{16}$.

The elevated cytokine levels may also be responsible for the lethal complications of patients with COVID-19, SARS or MERS presented distinct cytokine profiles ${ }^{17}$. Along with interleukins the levels of C-reactive protein(CRP), induced by IL-6, is a significant biomarker of inflammation, infection and tissue damage ${ }^{18}$ along with Procalcitonin (PCT) that is a glycoprotein and is the precursor of calcitonin, its levels are increased with bacterial and viral levels and can be indicative of the disease severity as these levels were found to be greater in severe group of patients 
than in mild group ${ }^{9}$. Ferritin, a protein that contains iron and is the primary form of iron stored inside of cells. Levels of ferritin could be a significant marker for COVID-19 as it is found elevated in diseased patients ${ }^{19}$.

To the best of our knowledge, due to the insufficient sample sizes, the complete inflammatory profile is missing to date. Therefore, we did a meta-analysis based on the current literature to compare the levels of inflammatory markers between severe vs non-severe and survivor vs non-survivors patients with COVID-19. Our findings will give insight about the role of inflammation in the pathophysiology of novel coronavirus and its clinical features. Detection of these inflammatory markers can work as a tool to group patients according to their disease severity and predict the prognosis and mortality, thereby contributing to treatment and reducing mortality rate.

\section{MATERIALS AND METHODS}

Preferred Reporting Items for Systematic Review and Meta-Analysis (PRISMA) guidelines extension for scoping reviews $^{20}$ and MOOSE guidelines were followed for designing and reporting this systematic review. The protocol of this systematic review was registered on PROSPERO (registration ID: CRD42020200757).

Data sources and searches

A systematic literature search was performed using Medline (via PubMed), The Cochrane Central Register of Controlled Trials (CENTRAL) and Clinicaltrials.gov until September 1, 2020 using the keywords "SARS CoV-2", “Interleukins”, "Cytokines”, “COVID-19”, “Cytokine storm”, "Inflammatory markers”, "laboratory findings”. We also searched grey literature using Google Scholar and reference list of eligible articles with the aim of identifying additional potential eligible studies. Each article was separately reviewed by two authors independently to find out the right content. The searches were limited to articles published in English language.

\section{Inclusion and exclusion criteria}


Observational studies or case series reporting the level of cytokines in defined groups as per severity of COVID-19 were included. We excluded duplicate publications, reviews, editorials, case reports, letters, meta-analysis, systematic review, protocols, studies in language other than English and studies not reporting the required data. First author (SK) searched data and screened articles for eligibility. Senior author (PM) double checked all the included articles and any dispute was resolved by the third author (RP).

\section{Quality assessment}

Two reviewers (SK and PM) assessed the quality of data in the included studies using the National Institute of Health (NIH) quality assessment tools ${ }^{21}$. We preferred the NIH tool because it is comprehensive and widely accepted for an exhaustive assessment of data quality. We rated the overall quality of included studies as good, fair and poor, and incorporated them in the results of this systematic review. The tools were designed to assist reviewers in focusing on concepts that are key for critical appraisal of the internal validity of a study. The tools were not designed to provide a list of factors comprising a numeric score. The tools were specific to individual types of included study designs and are described in more detail below. The tools included items for evaluating potential flaws in study methods or implementation, including sources of bias (e.g., patient selection, performance, attrition, and detection), confounding, study power, the strength of causality in the association between interventions and outcomes, and other factors. Quality reviewers could select "yes," "no," or "cannot determine/not reported/not applicable" in response to each item on the tool. For each item where "no" was selected, reviewers were instructed to consider the potential risk of bias that could be introduced by that flaw in the study design or implementation. Cannot determine and not reported were also noted as representing potential flaws. Each of the quality assessment tools had a detailed guidance document, which was also developed by the methodology team and NHLBI.

\section{Data Extraction and analysis}

Data was inputted into a standardized data extraction table (Excel) and independently checked by a second reviewer (PM) for accuracy. The following variables were extracted: name of the first author, year of publication, study design, age, gender, number of patients in severe and non-severe and survivor vs non-survivor groups, comorbidities, and the reported level of cytokines. The severity of disease was defined according to Diagnosis and Treatment Plan of COVID- 
19 issued by National Health Commission, China (7th edition) as mild, common, severe, and critical based on the clinical symptoms ${ }^{22}$. The articles that were included in this systematic review are displayed in PRISMA flow diagram

\section{(Figure-I).}

\section{Outcomes}

The primary outcomes were (1) Severity of COVID-19 including: Intensive Care Unit (ICU) admission and (2) mortality due to confirmed COVID-19. Only intra-hospital mortality was considered.

\section{Analysis plan}

We performed an exploratory meta-analysis to understand the magnitude and direction of effect estimate.

Continuous outcomes are presented using weighted mean difference (WMD) and 95\% confidence intervals (CIs). Odds ratios (ORs) were calculated and presented with respective 95\% CIs for binary outcomes. Meta-analysis of ORs using Mantel-Haenszel random-effects and inverse-variance method for WMDs using DerSimonian-Laird method was used ${ }^{23}$. Heterogeneity between studies was assessed using the $\chi^{2}$-based Cochran's $Q$ statistic ( $p<0.1$ considered as the presence of heterogeneity) and I-squared $\left(I^{2}\right)$ statistics $(>50 \%$ representing moderate heterogeneity) ${ }^{23}$. Publication bias was not assessed as a total number of studies for respective outcomes were less than ten ${ }^{23}$.

\section{RESULTS}

\section{Search Results}

The systematic search yielded a total of 838 publications. After removing duplicates, 313 articles were found to be potential publications for screening. After the application of predefined inclusion and exclusion criteria, a total of 21 studies were included for the final analysis (Figure-I).

\subsection{Study characteristics}

Among the 21 included studies, 16 were cohort studies, while 5 were case series. The main characteristics of the included studies are reported in Table-I. Overall, 4,023 participants were enrolled in the present study, out of which 
medRxiv preprint doi: https://doi.org/10.1101/2021.09.16.21263678; this version posted September 21, 2021. The copyright holder for this

preprint (which was not certified by peer review) is the author/funder, who has granted medRxiv a license to display the preprint in perpetuity.

It is made available under a CC-BY-NC-ND 4.0 International license .

2,190 (57.55\%) were male and 1,615 (42.44\%) were females. The patients were classified into 4 groups on the basis of their disease severity: severe and non-severe or survivor and non-survivor group. Severe group had a total of 1,242 patients (32.64 \%) whereas non -severe group had 2,563 patients (67.35\%). Survivor group had 425 patients (62.9\%) and Non- Survivor group had 250 patients (37.03\%). Inflammatory markers that were assessed in the present systematic review were IL-2, IL-2R, IL-4, IL-6, IL-8, IL-10, IL-1 $\beta$, TNF- $\alpha$, MCP-1, C-reactive protein, procalcitonin, and ferritin.

\subsection{Association of Cytokines with disease severity}

For the patients stratified by severity of COVID-19, the random effect results demonstrated statistically significant elevation of levels of IL-6 (WMD=18.17 95\%CI 3.38 to 32.96, p=0.016), IL-8 (WMD=12.09 95\%CI 4.41 to 19.77, $\mathrm{p}=0.002), \mathrm{MCP}-1$ (WMD=146.66 95\%CI 88.16 to 205.16, $\mathrm{p}<0.001$ ), CRP (WMD=31.09 95\%CI 10.08 to 52.10, $\mathrm{p}=0.004)$, PCT $(\mathrm{WMD}=-31.2395 \% \mathrm{CI}-37.70$ to $-24.76, \mathrm{p}<0.001), \mathrm{IL}-2 \mathrm{R}(\mathrm{WMD}=861.9395 \% \mathrm{CI} 275.45$ to 1448.41 , $\mathrm{p}=0.004)$, ferritin $(\mathrm{WMD}=1083.3495 \% \mathrm{CI} 431.99$ to $1734.70, \mathrm{p}=0.001)$ in severe group as compared to non-severe group. However, the levels of IL-4 (WMD= $-18.6395 \% \mathrm{CI}-51.499$ to $14.239, \mathrm{p}=0.267)$, IL-2 (WMD=6.76 95\%CI 0.936 to $14.462, \mathrm{p}=0.085), \mathrm{IL}-10$ (WMD=2.49 95\%CI -1.17 to $6.16, \mathrm{p}=0.182), \mathrm{TNF}-\alpha(\mathrm{WMD}=-3.0795 \% \mathrm{CI}-12.30$ to $6.15, \mathrm{p}=0.513$ ), IL-1 $(\mathrm{WMD}=13.7495 \% \mathrm{CI}-15.27$ to $42.75, \mathrm{p}=0.353$ ) were not found significantly associated with the disease severity in COVID-19 patients. Summary effects of all cytokines showed substantial heterogeneity between $\left(\mathrm{I}^{2} \sim 91-97 \%\right)$ contrasting with IL-1 $\beta$ where heterogeneity remained $\left(\mathrm{I}^{2} \sim 62 \%\right)$ in the patient groups as severe and non-severe across all 21 studies (Table-II) ${ }^{4,4,8,8,17,24-32}$.

\subsection{Association of Cytokines with mortality}

For the patients stratified by survival of COVID-19, the random effect results demonstrated statistically significant elevation of levels of IL-2R (WMD= $-666.0695 \% \mathrm{CI}-782.54$ to $-549.59, \mathrm{p}<0.001)$, IL-8 (WMD= $-26.6395 \% \mathrm{CI}$ 33.031 to $-20.236, \mathrm{p}<0.001), \mathrm{IL}-10(\mathrm{WMD}=-7.6095 \% \mathrm{CI}-8.93$ to $-6.26, \mathrm{p}<0.001), \mathrm{TNF}-\alpha(\mathrm{WMD}=-4.6095 \% \mathrm{CI}-$ 5.71 to $-3.48, \mathrm{p}<0.001)$, IL- $1 \beta$ (WMD=22.66 95\%CI 8.13 to $37.19, \mathrm{p}=0.002)$, CRP (WMD= -96.40 95\%CI -117.84 to $-74.97, \mathrm{p}<0.001)$, and ferritin ( $\mathrm{WMD}=-937.6095 \% \mathrm{CI}-1084.15$ to $-791.065, \mathrm{p}<0.001)$ in the survivor group as compared to non-survivor group. However, our observation reported levels of IL-6 ( $p=0.259)$, PCT $(p=0.529)$ were not significantly associated with the mortality. Substantial heterogeneity was observed in IL-6 (I $\left.{ }^{2} \sim 98.9 \%\right)$ 
in the patient groups as survivors and non-survivors across 3 studies ${ }^{17,26,33}$ (Table-II).

\subsection{Comorbidities}

None of the comorbidities were statistically associated with the mortality in COVID-19 patients [hypertension $(\mathrm{OR}=0.58,95 \% \mathrm{CI} 0.17$ to 1.96$)$, diabetes $(\mathrm{OR}=0.63,95 \% \mathrm{CI} 0.20$ to 1.93$), \mathrm{CVD}(\mathrm{OR}=0.96,95 \% \mathrm{CI} 0.07$ to 12.57$)$, $\mathrm{CHD}(\mathrm{OR}=2.72,95 \% \mathrm{CI} 0.59$ to 12.50$)$, $\mathrm{COPD}(\mathrm{OR}=0.62,95 \% \mathrm{CI} 0.15$ to 2.53$), \mathrm{CLD}(\mathrm{OR}=0.45,95 \% \mathrm{CI} 0.13$ to 1.50), $\mathrm{CKD}(\mathrm{OR}=0.73,95 \% \mathrm{CI} 0.01$ to 33.19), and cancer ( $\mathrm{OR}=2.22,95 \% \mathrm{CI} 0.20$ to 23.82)] (Table-III).

\section{DISCUSSION}

COVID-19 a speedily increasing pandemic declared as an emergency by WHO increasing the burden on medical facilities ${ }^{3}$ which is usually caused by cytokine storm which is the main factor driving severe clinical course of SARS-CoV-2 with a specific immune response that causes severe pathogenic mechanisms through inflammation in a way of 'attacking' the body which leads to severe pneumonia, pulmonary oedema, ARDS, or multiple organ failure, ICU admissions and even death ${ }^{5,7}$. Studies have demonstrated the levels of cytokines can also be related to severity of COVID-19 infection ${ }^{5,7,11}$. Reports suggest that in patients with severe COVID-19, higher levels of IL-2, IL-10, TNF- $\alpha$ are present in ICU patients compared to non-ICU ${ }^{12,14}$. Cytokines are quantitative measurements used clinically for many conditions reflecting pathological development of COVID-19 and evidence from literature depicts a major role of interleukins as an useful approach to clinicians for establishing a treatment and close monitoring and improving prognosis and outcomes and their significant variability between different groups of patients ${ }^{5}$. Cytokines drive T-cell growth, induces the differentiation of regulatory T-cells, and mediates activationinduced cell death ${ }^{34,35}$. IL-4 (IL-4R) signaling plays an essential role in immune responses through their signaling via type I and type II IL-4Rs on neutrophils to inhibition of several neutrophil effector functions fighting against infection at the site of infection ${ }^{36}$. IL-8 can add to neutrophil-mediated tissue damage, inflammatory diseases and host defense, neutrophils, granulocytes, causing migration toward the site of infection. ${ }^{37}$. IL-10, which is also to referred as human cytokine synthesis inhibitory factor (CSIF), acts as an anti-inflammatory cytokine ${ }^{38}$. IL-6 is an interleukin that acts as a pro-inflammatory cytokine ${ }^{15,39}$. Elevated levels of IL-6 can cause hyper-activation of JAK/STAT3 signaling, which is often associated with poor patient outcomes ${ }^{1640,41}$, implying a possible shared 
mechanism of cytokine-mediated lung damage caused by COVID-9 infection ${ }^{42,43}$ along with co-morbidities like hypertension in severe group of patients more than non-severe ones is contributing to disease severity and case fatality ${ }^{32}$. Therefore, it is imperative to recognize the markers observing the progression of disease and treat patients early. The elevated cytokine levels may also be responsible for the lethal complications of patients with COVID-19 ${ }^{17}$. Severity in COVID-19 may also be associated with IFN- $\gamma$ production by CD4+ T-cells as its defect may lead to hypercytokinaemia ${ }^{12}$. Along with interleukins, the levels of C-reactive protein (CRP), induced by IL-6, is a significant biomarker of inflammation, infection and tissue damage ${ }^{18}$. The correlation between CRP levels, lung lesions, and disease severity can provide reference for clinical treatment ${ }^{18,40}$. Procalcitonin (PCT) that is a glycoprotein and is the precursor of calcitonin, its levels are increased with bacterial and viral levels and can be indicative of the disease severity as these levels were found to be greater in severe group of patients than in mild group ${ }^{9,32}$ indicating its association with disease severity and mortality $4,6,8,19,24,27,28,30,32,33,44-47$. Ferritin, a protein that contains iron and is the primary form of iron stored inside of cells. Levels of ferritin could be a significant marker for COVID-19 as it is found elevated in diseased patients ${ }^{19}$ (S. Li et al., 2020; , Wu, Ke et al., 2020 ${ }^{4,30,32,48}$. Nevertheless, the role of inflammatory markers in observing the severity and mortality of COVID-19 is still controversial. In this study, through examining the 21 retrospective studies, we concluded that inflammatory markers were positively correlated with the severity and mortality of COVID-19.

Furthermore, categorizing patients into severe and non-severe sub-groups is dependent on the definitions of severity of COVID-19. The approach was to measure severity of the disease between two groups as it was found from different literature studies .A retrospective study of 552 patients stated panel of circulating cytokinesIL-2R, IL-6, IL8, IL-10, IL-1 $\beta$ and TNF $\alpha$, PCT, CRP and ferritin could predict disease deterioration as the levels of cytokines were greatly increased in the severe group of patients than the non-severe ones which in turn was associated with the severity and mortality risk ${ }^{46}$. A meta-analysis demonstrated IL-6, IL-10 and serum ferritin were significantly elevated in patients with both severe and fatal COVID-19 indicating these interleukins as a strong discriminators for severe disease ${ }^{49,50}$. Increased CRP, IL-6 and TNF- $\alpha$ in COVID-19 patients and has shown a significant role of these markers in disease prognosis ${ }^{31}$. Furthermore, a retrospective study on 83 patients demonstrated how cytokines can be a targeted approach for the treatment methods for COVID-19 with IL blocking agents for severely ill patients seems effective as it is essential to accomplish a treatment for patient's condition in a timely manner ${ }^{51}$. Moreover, 
medRxiv preprint doi: https://doi.org/10.1101/2021.09.16.21263678; this version posted September 21, 2021. The copyright holder for this

preprint (which was not certified by peer review) is the author/funder, who has granted medRxiv a license to display the preprint in perpetuity.

It is made available under a CC-BY-NC-ND 4.0 International license .

strategies that encourage pulmonary recruitment and over activation of inflammatory cells by suppressing cytokine storm might improve the outcomes of severe COVID-19 patients ${ }^{8}$. The above discussed findings show that more attention is warranted when interpreting cytokine findings in patients with COVID-19 as patients with highly increased levels require proper management .Furthermore, studies based on patients with co-morbidities like diabetes and hypertension, and age above 50 demonstrated greater risk of death in COVID-19 patients $^{52}$.

Multiple studies on COVID-19 have concurred high amount of information on cytokines and their use on the basis of their role in severity of the disease which independently has been suggested to give a potential approach for treatment of COVID-19 as patients have consistently high levels of cytokines, with significant co-morbidities such as diabetes, hypertension and CVD reported in critically ill patients. Therefore, further research on the same can give a better insight to the clinicians regarding the disease progression of patients. However, the role of inflammatory markers in monitoring the severity of COVID-19 is still controversial ${ }^{12}$. A copious amount of data was collected from different locations where different levels were seen in different patients amongst the same set of parameters taking in consideration the variability the study. Variability can be accounted to the differences in patient exposure to the virus. To ascertain the usefulness of the cytokines listed in this systematic review as indicators of disease progression, and whether they definitively rise in COVID-19 may require further data collection.

There are several limitations that needs to be mentioned. The number of studies included in the meta-analysis is small. There was heterogeneity amongst individual studies because of which there was a deviation of some of our results from usual findings. Additionally, case-series were included in the present meta-analysis. Although we did an extensive search, we may have inadvertently missed relevant studies. Exclusion of studies in languages other than English may have resulted in missing of relevant studies.

\section{CONCLUSION}

The present systematic review will provide understanding of the role of inflammatory markers in the pathophysiology of the disease COVID-19 which is associated with age and comorbidities donating to disease severity and mortality. The uncovering of these clinical parameters can contribute in the suitable diagnostic and treatment approach in a timely manner that can further help in the reduction of the mortality rate in the patients of 
COVID-19. Also, most of the studies referenced in this systematic review are cohort studies originating in Wuhan, China, but because the virus is now global pandemic it thus requires international studies with a bigger sample size with role of inflammatory markers in the disease diagnosis and prognosis.

\section{DECLARATIONS}

Funding: This research did not receive any specific grant from funding agencies in the public, commercial, or notfor-profit sectors.

Conflicts of interest/Competing interests: None

Availability of data and material (data transparency): The author confirms that the data supporting the findings of the study are available within the article [and/ or its supplementary material].

Code availability (software application or custom code): Not applicable

Authors' contributions: Conception and design- Nidhi and Pinki; acquisition of data- Sara and Pinki; analysis and interpretation of data- Rizwana and Ram; drafting the article- Sara and Pinki; revised article critically for important intellectual content- Nidhi and Rizwana; final approval of the version to be published- Nidhi

\section{References:}

1. Felsenstein S, Herbert JA, McNamara PS, Hedrich CM. COVID-19: Immunology and treatment options. Clin Immunol. 2020;215:108448. doi:10.1016/j.clim.2020.108448

2. WHO. Coronavirus disease (COVID-19) pandemic. World health organisation. Published 2020. Accessed June 1, 2020. https://www.who.int/emergencies/diseases/novel-coronavirus-2019

3. Kermali M, Khalsa RK, Pillai K, Ismail Z, Harky A. The role of biomarkers in diagnosis of COVID-19A systematic review. Life Sci. 2020;254:117788. doi:10.1016/j.Ifs.2020.117788

4. Wang D, Hu B, Hu C, et al. Clinical Characteristics of 138 Hospitalized Patients With 2019 Novel Coronavirus-Infected Pneumonia in Wuhan, China. JAMA. 2020;323(11):1061. doi:10.1001/jama.2020.1585 
medRxiv preprint doi: https://doi.org/10.1101/2021.09.16.21263678; this version posted September 21, 2021. The copyright holder for this preprint (which was not certified by peer review) is the author/funder, who has granted medRxiv a license to display the preprint in perpetuity.

It is made available under a CC-BY-NC-ND 4.0 International license .

5. Coperchini F, Chiovato L, Croce L, Magri F, Rotondi M. The cytokine storm in COVID-19: An overview of the involvement of the chemokine/chemokine-receptor system. Cytokine Growth Factor Rev. 2020;53:25-32. doi:10.1016/j.cytogfr.2020.05.003

6. Yang P, Ding Y, Xu Z, et al. Epidemiological and Clinical Features of COVID-19 Patients with and without Pneumonia in Beijing, China. Epidemiology; 2020. doi:10.1101/2020.02.28.20028068

7. Yao Z, Zheng Z, Wu K, Junhua Z. Immune environment modulation in pneumonia patients caused by coronavirus: SARS-CoV, MERS-CoV and SARS-CoV-2. Aging. 2020;12(9):7639-7651. doi:10.18632/aging.103101

8. Li S, Jiang L, Li X, et al. Clinical and pathological investigation of patients with severe COVID-19. JCI Insight. 2020;5(12):e138070. doi:10.1172/jci.insight.138070

9. Liu F, Li L, Xu M, et al. Prognostic value of interleukin-6, C-reactive protein, and procalcitonin in patients with COVID-19. J Clin Virol. 2020;127:104370. doi:10.1016/j.jcv.2020.104370

10. Xu Z, Shi L, Wang Y, et al. Pathological findings of COVID-19 associated with acute respiratory distress syndrome. Lancet Respir Med. 2020;8(4):420-422. doi:10.1016/S2213-2600(20)30076-X

11. AminJafari A, Ghasemi S. The possible of immunotherapy for COVID-19: A systematic review. Int Immunopharmacol. 2020;83:106455. doi:10.1016/j.intimp.2020.106455

12. McGonagle D, Sharif K, O'Regan A, Bridgewood C. The Role of Cytokines including Interleukin- 6 in COVID-19 induced Pneumonia and Macrophage Activation Syndrome-Like Disease. Autoimmun Rev. 2020;19(6):102537. doi:10.1016/j.autrev.2020.102537

13. Noroozi R, Branicki W, Pyrc K, et al. Altered cytokine levels and immune responses in patients with SARS-CoV-2 infection and related conditions. Cytokine. 2020;133:155143. doi:10.1016/j.cyto.2020.155143

14. Rahmati M. Cytokine-targeted therapy in severely ill COVID-19 patients: Options and cautions. Eurasian J Med Oncol. Published online 2020. doi:10.14744/ejmo.2020.72142

15. Tanaka T, Narazaki M, Kishimoto T. IL-6 in inflammation, immunity, and disease. Cold Spring Harb Perspect Biol. 2014;6(10):a016295. doi:10.1101/cshperspect.a016295

16. Johnson DE, O'Keefe RA, Grandis JR. Targeting the IL-6/JAK/STAT3 signalling axis in cancer. Nat Rev Clin Oncol. 2018;15(4):234-248. doi:10.1038/nrclinonc.2018.8

17. Zhou F, Yu T, Du R, et al. Clinical course and risk factors for mortality of adult inpatients with COVID-19 in Wuhan, China: a retrospective cohort study. The Lancet. 2020;395(10229):1054-1062. doi:10.1016/S0140-6736(20)30566-3

18. Wang L. C-reactive protein levels in the early stage of COVID-19. Médecine Mal Infect. 2020;50(4):332-334. doi:10.1016/j.medmal.2020.03.007

19. Wu C, Chen X, Cai Y, et al. Risk Factors Associated With Acute Respiratory Distress Syndrome and Death in Patients With Coronavirus Disease 2019 Pneumonia in Wuhan, China. JAMA Intern Med. 
medRxiv preprint doi: https://doi.org/10.1101/2021.09.16.21263678; this version posted September 21, 2021. The copyright holder for this preprint (which was not certified by peer review) is the author/funder, who has granted medRxiv a license to display the preprint in perpetuity.

It is made available under a CC-BY-NC-ND 4.0 International license .

Published online March 13, 2020. doi:10.1001/jamainternmed.2020.0994

20. Tricco AC, Lillie E, Zarin W, et al. PRISMA Extension for Scoping Reviews (PRISMA-ScR): Checklist and Explanation. Ann Intern Med. 2018;169(7):467. doi:10.7326/M18-0850

21. NIH. Study Quality Assesement Tools. Natioanl Heart, Lung and Blood Institute. Published 2020. Accessed July 10, 2020. https://www.nhlbi.nih.gov/health-topics/study-quality-assessment-tools

22. Peng F, Tu L, Yang Y, et al. Management and Treatment of COVID-19: The Chinese Experience. Can J Cardiol. 2020;36(6):915-930. doi:10.1016/j.cjca.2020.04.010

23. Higgins et al. et. Higgins JPT GS (March 2011) Cochrane Handbook for Systematic Reviews of Interventions. The Cochrane Collaboration. Cochrane Handbook for Systematic Reviews of Interventions. Published 2011. https://training.cochrane.org/handbook/current

24. Cai Q, Huang D, Ou P, et al. COVID-19 in a designated infectious diseases hospital outside Hubei Province, China. Allergy. Published online April 17, 2020:all.14309. doi:10.1111/all.14309

25. Chen G, Wu D, Guo W, et al. Clinical and immunological features of severe and moderate coronavirus disease 2019. J Clin Invest. 2020;130(5):2620-2629. doi:10.1172/JCI137244

26. Gao Y, Li T, Han M, et al. Diagnostic utility of clinical laboratory data determinations for patients with the severe COVID-19. J Med Virol. 2020;92(7):791-796. doi:10.1002/jmv.25770

27. Guan W, Ni Z, Hu Y, et al. Clinical Characteristics of 2019 Novel Coronavirus Infection in China. Respiratory Medicine; 2020. doi:10.1101/2020.02.06.20020974

28. Herold T, Jurinovic V, Arnreich C, et al. Level of IL-6 Predicts Respiratory Failure in Hospitalized Symptomatic COVID-19 Patients. Infectious Diseases (except HIV/AIDS); 2020. doi:10.1101/2020.04.01.20047381

29. Li K, Wu J, Wu F, et al. The Clinical and Chest CT Features Associated With Severe and Critical COVID-19 Pneumonia: Invest Radiol. 2020;55(6):327-331. doi:10.1097/RLI.0000000000000672

30. Wu, Ke C, Chen X, Cai Y, et al. Risk Factors Associated With Acute Respiratory Distress Syndrome and Death in Patients With Coronavirus Disease 2019 Pneumonia in Wuhan, China. JAMA Intern Med. Published online March 13, 2020. doi:10.1001/jamainternmed.2020.0994

31. Zhang Z-L, Hou Y-L, Li D-T, Li F-Z. Laboratory findings of COVID-19: a systematic review and metaanalysis. Scand J Clin Lab Invest. Published online May 23, 2020:1-7. doi:10.1080/00365513.2020.1768587

32. Zhu Z, Cai T, Fan $L$, et al. Clinical value of immune-inflammatory parameters to assess the severity of coronavirus disease 2019. Int J Infect Dis. 2020;95:332-339. doi:10.1016/j.ijid.2020.04.041

33. Chen $\mathrm{T}, \mathrm{Wu} \mathrm{D}, \mathrm{Chen} \mathrm{H}$, et al. Clinical characteristics of 113 deceased patients with coronavirus disease 2019: retrospective study. BMJ. 2020;368:m1091. doi:10.1136/bmj.m1091

34. Liao W, Lin J-X, Leonard WJ. IL-2 family cytokines: new insights into the complex roles of IL-2 as a 
medRxiv preprint doi: https://doi.org/10.1101/2021.09.16.21263678; this version posted September 21, 2021. The copyright holder for this preprint (which was not certified by peer review) is the author/funder, who has granted medRxiv a license to display the preprint in perpetuity.

It is made available under a CC-BY-NC-ND 4.0 International license .

broad regulator of Thelper cell differentiation. Curr Opin Immunol. 2011;23(5):598-604. doi:10.1016/j.coi.2011.08.003

35. Liu Z, Long W, Tu M, et al. Lymphocyte subset (CD4+, CD8+) counts reflect the severity of infection and predict the clinical outcomes in patients with COVID-19. J Infect. Published online April 2020:S0163445320301821. doi:10.1016/j.jinf.2020.03.054

36. Egholm C, Heeb LEM, Impellizzieri D, Boyman O. The Regulatory Effects of Interleukin-4 Receptor Signaling on Neutrophils in Type 2 Immune Responses. Front Immunol. 2019;10:2507. doi:10.3389/fimmu.2019.02507

37. Moore BB, Kunkel SL. Attracting Attention: Discovery of IL-8/CXCL8 and the Birth of the Chemokine Field. J Immunol. 2019;202(1):3-4. doi:10.4049/jimmunol.1801485

38. Wang X, Wong K, Ouyang W, Rutz S. Targeting IL-10 Family Cytokines for the Treatment of Human Diseases. Cold Spring Harb Perspect Biol. 2019;11(2). doi:10.1101/cshperspect.a028548

39. Uciechowski P, Dempke WCM. Interleukin-6: A Masterplayer in the Cytokine Network. Oncology. 2020;98(3):131-137. doi:10.1159/000505099

40. lei liu, Jian-ya G. Clinical Characteristics of 51 Patients Discharged from Hospital with COVID-19 in Chongqing, China. Infectious Diseases (except HIV/AIDS); 2020.

doi:10.1101/2020.02.20.20025536

41. Wang H, Luo S, Shen Y, et al. Multiple Enzyme Release, Inflammation Storm and Hypercoagulability Are\&nbsp;Prominent Indicators\&nbsp;For Disease Progression\&nbsp;In COVID-19: A MultiCentered, Correlation\&nbsp;Study with CT Imaging Score. SSRN Electron J. Published online 2020. doi:10.2139/ssrn.3544837

42. Liu J, Ouyang L, Guo P, et al. Epidemiological, Clinical Characteristics and Outcome of Medical Staff Infected with COVID-19 in Wuhan, China: A Retrospective Case Series Analysis. Infectious Diseases (except HIV/AIDS); 2020. doi:10.1101/2020.03.09.20033118

43. Ulhaq ZS, Soraya GV. Interleukin- 6 as a potential biomarker of COVID-19 progression. Médecine Mal Infect. 2020;50(4):382-383. doi:10.1016/j.medmal.2020.04.002

44. Gao S, Jiang F, Jin W, et al. Risk factors influencing the prognosis of elderly patients infected with COVID-19: a clinical retrospective study in Wuhan, China. Aging. 2020;12.

doi:10.18632/aging.103631

45. Gao Y, Li T, Han M, et al. Diagnostic utility of clinical laboratory data determinations for patients with the severe COVID-19. J Med Virol. 2020;92(7):791-796. doi:10.1002/jmv.25770

46. Qin C, Zhou L, Hu Z, et al. Dysregulation of Immune Response in Patients With Coronavirus 2019 (COVID-19) in Wuhan, China. Clin Infect Dis. Published online March 12, 2020:ciaa248. doi:10.1093/cid/ciaa248

47. Zhang J, Dong X, Cao Y, et al. Clinical characteristics of 140 patients infected with SARS-CoV-2 in Wuhan, China. Allergy. Published online February 27, 2020:all.14238. doi:10.1111/all.14238 
medRxiv preprint doi: https://doi.org/10.1101/2021.09.16.21263678; this version posted September 21, 2021. The copyright holder for this preprint (which was not certified by peer review) is the author/funder, who has granted medRxiv a license to display the preprint in perpetuity.

It is made available under a CC-BY-NC-ND 4.0 International license.

48. Cai Q, Huang D, Ou P, et al. COVID-19 in a designated infectious diseases hospital outside Hubei Province, China. Allergy. Published online April 17, 2020:all.14309. doi:10.1111/all.14309

49. Dhar SK, K V, Damodar S, Gujar S, Das M. IL-6 and IL-10 as Predictors of Disease Severity in COVID 19 Patients: Results from Meta-Analysis and Regression. Infectious Diseases (except HIV/AIDS); 2020. doi:10.1101/2020.08.15.20175844

50. Henry BM, de Oliveira MHS, Benoit S, Plebani M, Lippi G. Hematologic, biochemical and immune biomarker abnormalities associated with severe illness and mortality in coronavirus disease 2019 (COVID-19): a meta-analysis. Clin Chem Lab Med. 2020;58(7):1021-1028. doi:10.1515/cclm-20200369

51. Luo P, Liu Y, Qiu L, Liu X, Liu D, Li J. Tocilizumab treatment in COVID-19: A single center experience. J Med Virol. 2020;92(7):814-818. doi:10.1002/jmv.25801

52. Guzik TJ, Mohiddin SA, Dimarco A, et al. COVID-19 and the cardiovascular system: implications for risk assessment, diagnosis, and treatment options. Cardiovasc Res. Published online April 30, 2020:cvaa106. doi:10.1093/cvr/cvaa106 
medRxiv preprint doi: https://doi.org/10.1101/2021.09.16.21263678; this version posted September 21, 2021. The copyright holder for this preprint (which was not certified by peer review) is the author/funder, who has granted medRxiv a license to display the preprint in perpetuity.

It is made available under a CC-BY-NC-ND 4.0 International license .

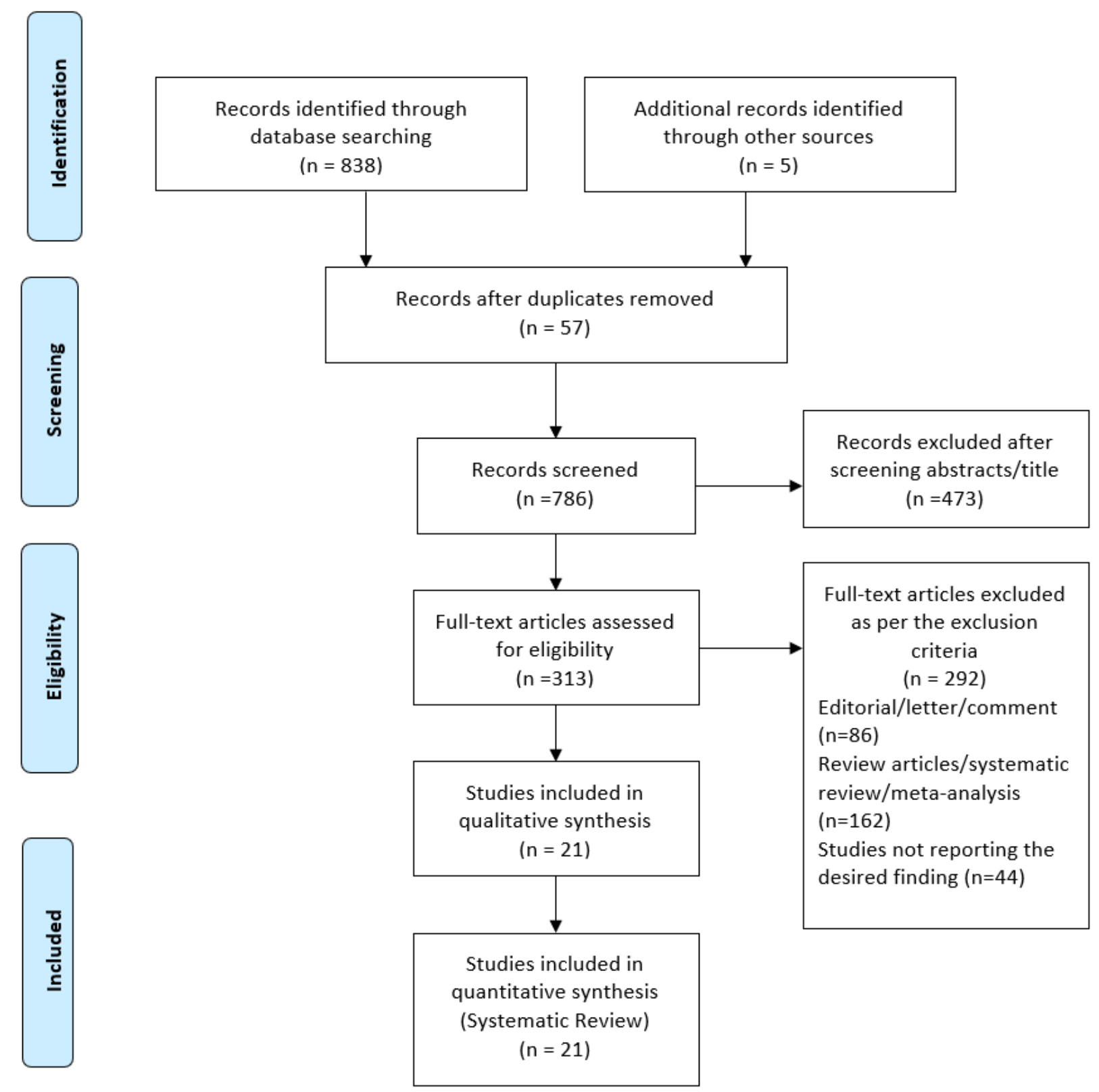

Figure-I PRISMA flow diagram 
Table-I Study Characteristics

\begin{tabular}{|c|c|c|c|c|c|c|c|c|c|c|}
\hline \multirow{2}{*}{$\begin{array}{l}\text { Author and } \\
\text { year }\end{array}$} & \multirow{2}{*}{$\begin{array}{l}\text { Study } \\
\text { design }\end{array}$} & \multirow[t]{2}{*}{ Country } & \multirow[t]{2}{*}{ Groups } & \multirow{2}{*}{$\begin{array}{l}\text { No. of } \\
\text { participants }\end{array}$} & \multirow{2}{*}{$\begin{array}{l}\text { Age } \\
\text { Median } \\
\text { (Range)/ } \\
\text { Mean (SD) }\end{array}$} & \multicolumn{2}{|l|}{ Sex } & \multirow[t]{2}{*}{ Comorbidity } & \multirow[t]{2}{*}{ Outcome } & \multirow{2}{*}{$\begin{array}{l}\text { Quality } \\
\text { Index }\end{array}$} \\
\hline & & & & & & $\begin{array}{l}\text { Male } \\
\text { n }(\%)\end{array}$ & $\begin{array}{l}\text { Female } \\
\text { n }(\%)\end{array}$ & & & \\
\hline \multirow[t]{3}{*}{$\begin{array}{l}\text { Shaohua et } \\
\text { al } 2020\end{array}$} & \multirow[t]{3}{*}{ Case series } & \multirow[t]{3}{*}{ China } & Total & 69 & $64(49-73)$ & $40(57.97)$ & $29(42)$ & \multirow{3}{*}{$\begin{array}{l}\text { DIA, HTN, } \\
\text { CVD, CLD, } \\
\text { Cancer, CRD }\end{array}$} & \multirow[t]{3}{*}{ Severity } & \multirow[t]{3}{*}{ Good } \\
\hline & & & Severe & $26(37.68)$ & $58(45-75)$ & $14(20.28)$ & $12(17.39)$ & & & \\
\hline & & & Non-severe & $43(62.31)$ & $39(29-53$ & $26(37.68)$ & $17(24.63)$ & & & \\
\hline \multirow[t]{3}{*}{$\begin{array}{l}\text { Cai et al } \\
2020\end{array}$} & \multirow[t]{3}{*}{ Cohort } & \multirow[t]{3}{*}{ China } & Total & 298 & $47.5(33-61)$ & $145(48.65)$ & $11(3.69)$ & \multirow{3}{*}{$\begin{array}{l}\text { DIA, HTN, } \\
\text { CVD, CLD, } \\
\text { Cancer }\end{array}$} & \multirow[t]{3}{*}{ Severity } & \multirow[t]{3}{*}{ Fair } \\
\hline & & & Severe & $58(19.4)$ & $62.5(56-66)$ & $39(13)$ & $16(5.36)$ & & & \\
\hline & & & Non-severe & $21(7.05)$ & $41(31-56)$ & $106(35.57)$ & $56(18.79)$ & & & \\
\hline \multirow{3}{*}{$\begin{array}{l}\text { Qin et al } \\
2020\end{array}$} & \multirow[t]{3}{*}{ Cohort } & \multirow[t]{3}{*}{ China } & Total & 452 & $58(47-67)$ & $235(52.0)$ & $217(48.0)$ & \multirow{3}{*}{$\begin{array}{l}\text { DIA, HTN, } \\
\text { CVD, COPD, } \\
\text { TB, Cancer, } \\
\text { CKD, CLD }\end{array}$} & \multirow[t]{3}{*}{ Severity } & \multirow[t]{3}{*}{ Good } \\
\hline & & & Severe & $286(63.27)$ & $61(51-69)$ & $155(54.2)$ & $131(45.8)$ & & & \\
\hline & & & Non-severe & $166(36.7)$ & $53(41.25-62)$ & $80(48.2)$ & $86(51.8)$ & & & \\
\hline \multirow[t]{3}{*}{$\begin{array}{l}\text { Wang et al } \\
2020\end{array}$} & \multirow[t]{3}{*}{ Case series } & \multirow[t]{3}{*}{ China } & Total & 28 & $68.6 \pm 9.0$ & $21(75.0)$ & $7(25.0)$ & \multirow[t]{3}{*}{$\begin{array}{l}\text { HTN, CVD, } \\
\text { COPD }\end{array}$} & Severity & Good \\
\hline & & & Severe & $14(50)$ & $71.4 \pm 7.9$ & $10(71.4)$ & 4 (28.6) & & & \\
\hline & & & Non-severe & $14(50)$ & $65.8 \pm 9.4$ & $11(78.6)$ & $3(21.4)$ & & & \\
\hline $\begin{array}{l}\text { Zhua et al } \\
2020\end{array}$ & Case series & China & Total & 127 & $50.9 \pm 15.26$ & $82(64.5)$ & $45(35.4)$ & $\begin{array}{l}\text { DIA, HTN, } \\
\text { CVD, COPD, }\end{array}$ & Severity & Fair \\
\hline & & & Severe & $16(12.5)$ & $49.95 \pm 15.52$ & $9(7)$ & $7(5.51)$ & Cancer, CLD & & \\
\hline & & & Non-severe & $111(87.4)$ & $57.50 \pm 11.70$ & $73(57.4)$ & $38(29.9)$ & & & \\
\hline Wu et al & Cohort & China & Total & 201 & $51(43-60)$ & $128(63.7)$ & $73(36.3)$ & Cancer, DIA, & Severity & Good \\
\hline & & & Severe & 84 (41.79) & $\begin{array}{l}58.5(50.0- \\
69.0)\end{array}$ & $60(71.4)$ & $24(28.6)$ & HTN & & \\
\hline & & & Non-severe & $117(58.20)$ & $\begin{array}{l}48.0(40.0- \\
54.0)\end{array}$ & $68(58.1)$ & $49(41.9)$ & & & \\
\hline Li et al 2020 & Cohort & China & Total & 83 & $45.5(12.3)$ & $44(53)$ & $39(47)$ & COPD, CVD, & Severity & Good \\
\hline & & & Severe & $25(30.12)$ & $53.7(12.3)$ & $15(60)$ & $10(40)$ & HTN, DIA & & \\
\hline & & & Non-severe & $58(69.87)$ & $41.9(10.6)$ & $29(50)$ & $29(50)$ & & & \\
\hline $\begin{array}{l}\text { Zhang et al } \\
2020\end{array}$ & Cohort & China & Total & 140 & $57(25-87)$ & $71(50.7)$ & $69(49.3)$ & $\begin{array}{l}\text { CLD, COPD } \\
\text { CHD, DIA }\end{array}$ & Severity & Good \\
\hline
\end{tabular}




\begin{tabular}{|c|c|c|c|c|c|c|c|c|c|c|}
\hline & \multirow{3}{*}{ Cohort } & \multirow{3}{*}{ China } & Severe & $58(41.42)$ & $64(25-87)$ & 33 56.9) & $25(43.1)$ & HTN & & \\
\hline & & & Severe & $13(31.70)$ & $\begin{array}{l}49 \cdot 0(41 \cdot 0- \\
61 \cdot 0)\end{array}$ & $11(85)$ & $2(15)$ & \multirow{2}{*}{$\begin{array}{l}\text { CLD, Cancer } \\
\text { COPD, DIA } \\
\text { HTN, CVD }\end{array}$} & \multirow{2}{*}{ Severity } & \multirow{2}{*}{ Good } \\
\hline & & & Non-severe & $28(68.29)$ & $\begin{array}{l}49 \cdot 0(41 \cdot 0- \\
57 \cdot 5)\end{array}$ & $19(68)$ & $9(32)$ & & & \\
\hline $\begin{array}{l}\text { Gao et al } \\
2020\end{array}$ & Cohort & China & Total & 43 & NA & 26 & 17 & $\begin{array}{l}\text { COPD, CVD, } \\
\text { DIA, HTN }\end{array}$ & Severity & Good \\
\hline \multirow{3}{*}{$\begin{array}{l}\text { Chen et al } \\
2020\end{array}$} & Cohort & China & Total & 21 & $56(50.0-65.0)$ & 17 & NA & \multirow[t]{3}{*}{ DIA, HTN } & \multirow[t]{3}{*}{ Severity } & \multirow[t]{3}{*}{ Fair } \\
\hline & & & Severe & $11(52.38)$ & $61(56.5-66.0)$ & 10 & NA & & & \\
\hline & & & Non-severe & $10(47.61)$ & $52(42.8-56.0)$ & 7 & NA & & & \\
\hline $\begin{array}{l}\text { Tao et al } \\
2020\end{array}$ & Cohort & China & Total & 274 & $\begin{array}{l}62.0(44.0- \\
70.0)\end{array}$ & $171(62)$ & $103(8)$ & $\begin{array}{l}\text { CKD, Cancer, } \\
\text { CVD, HTN, } \\
\text { DIA }\end{array}$ & Death & Good \\
\hline \multirow{2}{*}{$\begin{array}{l}\text { Gao et al } \\
2020\end{array}$} & & & $\begin{array}{l}\text { Non- } \\
\text { survivors }\end{array}$ & 35 (16.66) & $74(70-82)$ & $22(63)$ & $13(37)$ & \multirow{2}{*}{$\begin{array}{l}\text { CLD, CKD, } \\
\text { Cancer, CRD, } \\
\text { COPD, CHD } \\
\text { HTN, DIA }\end{array}$} & \multirow{2}{*}{ Death } & \multirow{2}{*}{ Good } \\
\hline & & & Survivors & $175(83.33)$ & $70(67-74)$ & $79(45)$ & $96(55)$ & & & \\
\hline \multirow[t]{3}{*}{$\begin{array}{l}\text { Guan et al } \\
2020\end{array}$} & Cohort & China & Total & 1099 & $\begin{array}{l}47.0(35.0- \\
58.0)\end{array}$ & NA & NA & \multirow{3}{*}{$\begin{array}{l}\text { Cancer, COPD, } \\
\text { HTN, DIA } \\
\text { CVD }\end{array}$} & \multirow[t]{3}{*}{ Severity } & \multirow[t]{2}{*}{ Good } \\
\hline & & & Severe & $173(1.58)$ & $\begin{array}{l}52.0(40.0- \\
65.0)\end{array}$ & NA & NA & & & \\
\hline & & & Non-severe & $926(84.25)$ & $\begin{array}{l}45.0(34.0- \\
57.0)\end{array}$ & NA & NA & & & \\
\hline \multirow[t]{2}{*}{$\begin{array}{l}\text { Wan et al } \\
2020\end{array}$} & Case series & China & Total & 135 & 47 (36-55) & $72(53.3)$ & $63(46.7)$ & \multirow{2}{*}{$\begin{array}{l}\text { CLD, Cancer } \\
\text { CVD, HTN, } \\
\text { DIA }\end{array}$} & \multirow[t]{2}{*}{ Severity } & Fair \\
\hline & & & Severe & $40(29.62)$ & $56(52-73)$ & $21(52.5)$ & $19(47.5)$ & & & \\
\hline
\end{tabular}




\begin{tabular}{|c|c|c|c|c|c|c|c|c|c|c|}
\hline & & & Severe & $24(25.80)$ & $57.9 \pm 11.8$ & 18 & 6 & HTN & & \\
\hline & & & Non-severe & 69 (74.19) & $42.1 \pm 18.6$ & 38 & 31 & & & \\
\hline \multirow[t]{3}{*}{$\begin{array}{l}\text { Zhou et al } \\
2020\end{array}$} & Cohort & China & Total & 191 & $\begin{array}{l}56 \cdot 0(46 \cdot 0- \\
67 \cdot 0)\end{array}$ & $119(62)$ & $72(38)$ & \multirow{3}{*}{$\begin{array}{l}\text { HTN, DIA } \\
\text { CHD, COPD, } \\
\text { CRD, CKD, } \\
\text { Cancer }\end{array}$} & \multirow[t]{3}{*}{ Death } & \multirow[t]{3}{*}{ Fair } \\
\hline & & & $\begin{array}{l}\text { Non- } \\
\text { survivors }\end{array}$ & $54(28.27)$ & $\begin{array}{l}69 \cdot 0(63 \cdot 0- \\
76 \cdot 0)\end{array}$ & $38(70)$ & $16(30)$ & & & \\
\hline & & & Survivors & $137(71.72)$ & $\begin{array}{l}52 \cdot 0(45 \cdot 0- \\
58 \cdot 0\end{array}$ & $81(59)$ & $56(41)$ & & & \\
\hline \multirow[t]{3}{*}{$\begin{array}{l}\text { Zhao et al } \\
2020\end{array}$} & Case series & China & Total & 29 & $\begin{array}{l}56.0(31.5- \\
66.0)\end{array}$ & $14(48.3)$ & $15(51.7)$ & \multirow[t]{3}{*}{ CRD, DIA } & \multirow[t]{3}{*}{ Severity } & \multirow[t]{3}{*}{ Good } \\
\hline & & & Severe & $8(27.58)$ & $\begin{array}{l}59.0(48.5- \\
75.0)\end{array}$ & $13(61.9)$ & $8(38.1)$ & & & \\
\hline & & & Non-severe & $17(58.62)$ & $\begin{array}{l}31.0(25.8- \\
53.3)\end{array}$ & $2(25)$ & $6(75)$ & & & \\
\hline \multirow[t]{3}{*}{$\begin{array}{l}\text { Li et al } \\
2020\end{array}$} & Cohort & China & Total & 325 & $51(36-64)$ & $167(51.4)$ & $158(48.6)$ & \multirow{3}{*}{$\begin{array}{l}\text { CLD, CKD, } \\
\text { Cancer, DIA } \\
\text { COPD, CVD, } \\
\text { HTN }\end{array}$} & \multirow[t]{3}{*}{ Severity } & \multirow[t]{3}{*}{ Gooc } \\
\hline & & & Severe & $26(8.00)$ & $65(63-76)$ & $20(76.9)$ & $6(23.1)$ & & & \\
\hline & & & Non-severe & $299(92.00)$ & $49(35-63)$ & 147 (49.2) & $152(50.8)$ & & & \\
\hline \multirow{3}{*}{$\begin{array}{l}\text { Chen et al } \\
2020\end{array}$} & Cohort & China & Total & 145 & NA & NA & NA & \multirow{3}{*}{$\begin{array}{l}\text { CLD, CKD, } \\
\text { COPD, HTN, } \\
\text { DIA }\end{array}$} & \multirow[t]{3}{*}{ Severity } & \multirow[t]{3}{*}{ Good } \\
\hline & & & Severe & $102(70.34)$ & $52.8 \pm 15.5$ & $23(53.5)$ & NA & & & \\
\hline & & & Non-severe & $103(71.03)$ & $45.3 \pm 13.6$ & $56(54.9)$ & NA & & & \\
\hline \multirow[t]{3}{*}{$\begin{array}{l}\text { Herold et al } \\
2020\end{array}$} & Cohort & China & Total & 40 & $57(19-81)$ & $29(72)$ & NA & \multirow[t]{3}{*}{$\begin{array}{l}\text { COPD, CHD, } \\
\text { DIA, HTN }\end{array}$} & \multirow[t]{3}{*}{ Severity } & \multirow[t]{3}{*}{ Good } \\
\hline & & & Severe & $13(32.5)$ & $64(45-81)$ & 13 (100) & NA & & & \\
\hline & & & Non-severe & $27(67.5)$ & $54(19-80)$ & $16(59)$ & NA & & & \\
\hline
\end{tabular}

CVD-Cardio vascular disease; CHD-Coronary heart disease; COPD-chronic obstructive pulmonary disease; CRD-chronic renal disease; CKD- chronic kidney

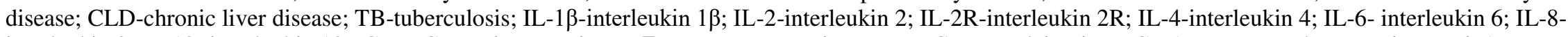
interleukin 8; IL-10- interleukin 10 ; CRP- C-reactive protein; TNF $\alpha$ - Tumor Necrosis Factor; PCT-Procalcitonin; MCP-1 Monocyte chemotactic protein1. 
Table-II Results of meta-analysis comparing laboratory abnormalities in COVID-19 patients with and without severe illness and mortality

\begin{tabular}{|c|c|c|c|c|c|c|c|c|c|c|}
\hline \multirow{2}{*}{$\begin{array}{l}\text { Laboratory } \\
\text { parameter }\end{array}$} & \multicolumn{5}{|c|}{ Severe vs Non-severe } & \multicolumn{5}{|c|}{ Survivors vs Non- survivors } \\
\hline & $\begin{array}{l}\text { No. of } \\
\text { Studies } \\
\text { (patients) }\end{array}$ & WMD & $95 \% \mathrm{CI}$ & $p$-value & $I^{2}(\%)$ & $\begin{array}{l}\text { No. of } \\
\text { Studies } \\
\text { (patients) }\end{array}$ & WMD & $95 \% \mathrm{CI}$ & $\begin{array}{r}p- \\
\text { value }\end{array}$ & $I^{2}(\%)$ \\
\hline IL-6(pg/mL) & $9(1344)$ & 18.172 & 3.384 to 32.96 & 0.016 & 93.1 & $2(465)$ & -37.142 & -101.654 to 27.37 & 0.259 & 98.9 \\
\hline IL-8(pg/mL) & $5(961)$ & 12.094 & 4.411 to 19.777 & 0.002 & 95.2 & $1(274)$ & -26.633 & -33.031 to -20.236 & $\begin{array}{l}\mathrm{p}<0.00 \\
1\end{array}$ & - \\
\hline IL-10 (pg/mL) & $6(790)$ & 2.496 & -1.172 to 6.164 & 0.182 & 91.7 & $1(274)$ & -7.6 & -8.934 to -6.266 & $\begin{array}{l}\mathrm{p}<0.00 \\
1\end{array}$ & - \\
\hline $\begin{array}{l}\mathrm{TNF}-\alpha \mathrm{pg} / \mathrm{mL} \\
(<8.1)\end{array}$ & $6(790)$ & -3.079 & -12.307 to 6.15 & 513 & 97.0 & $1(274)$ & -4.6 & -5.715 to -3.485 & $\begin{array}{l}\mathrm{p}<0.00 \\
1\end{array}$ & - \\
\hline $\mathrm{IL}-1 \beta(\mathrm{pg} / \mathrm{mL})$ & $4(635)$ & 13.742 & -15.27 to 42.754 & 0.105 & 62.0 & $1(274)$ & 22.667 & 8.136 to 37.197 & 0.002 & - \\
\hline MCP-1 (pg/mL) & $1(69)$ & 146.67 & 88.166 to 205.17 & 0.535 & - & - & - & - & 0 & - \\
\hline CRP (mg/L) & $13(3123)$ & 31.091 & 10.081 to 52.101 & 0.004 & 97.6 & $2(484)$ & -96.408 & -117.84 to -74.975 & $\begin{array}{l}\mathrm{p}<0.00 \\
1\end{array}$ & 70.4 \\
\hline PCT (ng/mL) & 14 (2919) & -31.24 & -37.706 to -24.77 & $\mathrm{p}<0.001$ & 99.3 & $2(675)$ & 2.952 & -6.237 to 12.141 & 0.529 & 65.5 \\
\hline $\mathrm{IL}-2 \mathrm{R}(\mathrm{U} / \mathrm{mL})$ & $4(628)$ & 861.931 & $\begin{array}{l}275.452 \text { to } \\
1448.410\end{array}$ & 0.004 & 99.7 & $1(274)$ & -666.067 & -782.543 to -549.591 & $\begin{array}{l}\mathrm{p}<0.00 \\
1\end{array}$ & - \\
\hline Ferritin, $\mu \mathrm{g} / \mathrm{L}$ (30- & $4(702)$ & 1083.3 & 432 to 1734.7 & $\mathrm{p}<0.001$ & 95.0 & $2(465)$ & -937.606 & -1084.15 to -791.065 & $\begin{array}{l}\mathrm{p}<0.00 \\
1\end{array}$ & 0.0 \\
\hline IL-4 (pg/mL) & $2(220)$ & -18.63 & -51.499 to14.239 & 0.267 & 91.2 & - & - & - & 0 & - \\
\hline $\mathrm{IL}-2(\mathrm{pg} / \mathrm{mL})$ & $1(93)$ & 6.763 & -0.936 to 14.462 & 0.085 & - & - & - & - & 0 & - \\
\hline
\end{tabular}

IL-1 $\beta$-interleukin 1 $\beta$; IL-2-interleukin 2; IL-2R-interleukin 2R; IL-4-interleukin 4; IL-6- interleukin 6; IL-8- interleukin 8; IL-10- interleukin 10; CRP- C-reactive protein; TNF $\alpha$ - Tumor Necrosis Factor: PCT-Procalcitonin; MCP-1 Monocyte chemotactic protein1 WMD weight mean difference; CI confidence interval. 
Table-III: Results of meta-analysis comparing co-morbidities, complications, and clinical outcome in COVID-19 patients with and without severe illness and mortality

\begin{tabular}{llllll}
\hline Comorbidity & No of studies (participants) & OR & 95\% CI & p-value & $\mathbf{I}^{\mathbf{2}(\%)}$ \\
\hline CHD & $1(191)$ & 2.72 & 0.59 to 12.50 & 0.197 & - \\
CKD & $2(484)$ & 0.73 & 0.01 to 33.19 & 0.897 & 89.9 \\
CLD & $2(401)$ & 0.45 & 0.13 to 1.50 & 0.198 & 9.4 \\
COPD & $2(401)$ & 0.62 & 0.15 to 2.53 & 0.507 & 0.0 \\
CVD & $2(484)$ & 0.96 & 0.07 to 12.57 & 0.979 & 94.6 \\
Cancer/Tumor & $3(675)$ & 2.22 & 0.20 to 23.82 & 0.509 & 77.8 \\
Diabetes & $3(675)$ & 0.63 & 0.20 to 1.93 & 0.423 & 85.2 \\
Hypertension & $3(675)$ & 0.58 & 0.17 to 1.96 & 0.387 & 90.7 \\
\hline
\end{tabular}

CVD-Cardio vascular disease; CHD-Coronary heart disease; COPD-chronic obstructive pulmonary disease; CRD-chronic renal disease; CKD- chronic kidney disease; CLD-chronic liver disease; TB-tuberculosis; OR odds ratio; CI confidence interval 
medRxiv preprint doi: https://doi.org/10.1101/2021.09.16.21263678; this version posted September 21, 2021. The copyright holder for this preprint (which was not certified by peer review) is the author/funder, who has granted medRxiv a license to display the preprint in perpetuity.

It is made available under a CC-BY-NC-ND 4.0 International license .

\section{ICMJE DISCLOSURE FORM}

Date:

Your Name:

Manuscript Title:
$9 / 16 / 2021$

Nidhi B Agarwal

Association of inflammatory markers with severity of disease and mortality in COVID-19 patients: a systematic review and meta-analysis

\section{Manuscript Number (if known): $\quad$ Click or tap here to enter text.}

In the interest of transparency, we ask you to disclose all relationships/activities/interests listed below that are related to the content of your manuscript. "Related" means any relation with for-profit or not-for-profit third parties whose interests may be affected by the content of the manuscript. Disclosure represents a commitment to transparency and does not necessarily indicate a bias. If you are in doubt about whether to list a relationship/activity/interest, it is preferable that you do so.

In the interest of transparency, we ask you to disclose all relationships/activities/interests listed below that are related to the content of your manuscript. "Related" means any relation with for-profit or not-for-profit third parties whose interests may be affected by the content of the manuscript. Disclosure represents a commitment to transparency and does not necessarily indicate a bias. If you are in doubt about whether to list a relationship/activity/interest, it is preferable that you do so.

The author's relationships/activities/interests should be defined broadly. For example, if your manuscript pertains to the epidemiology of hypertension, you should declare all relationships with manufacturers of antihypertensive medication, even if that medication is not mentioned in the manuscript.

In item \#1 below, report all support for the work reported in this manuscript without time limit. For all other items, the time frame for disclosure is the past 36 months.

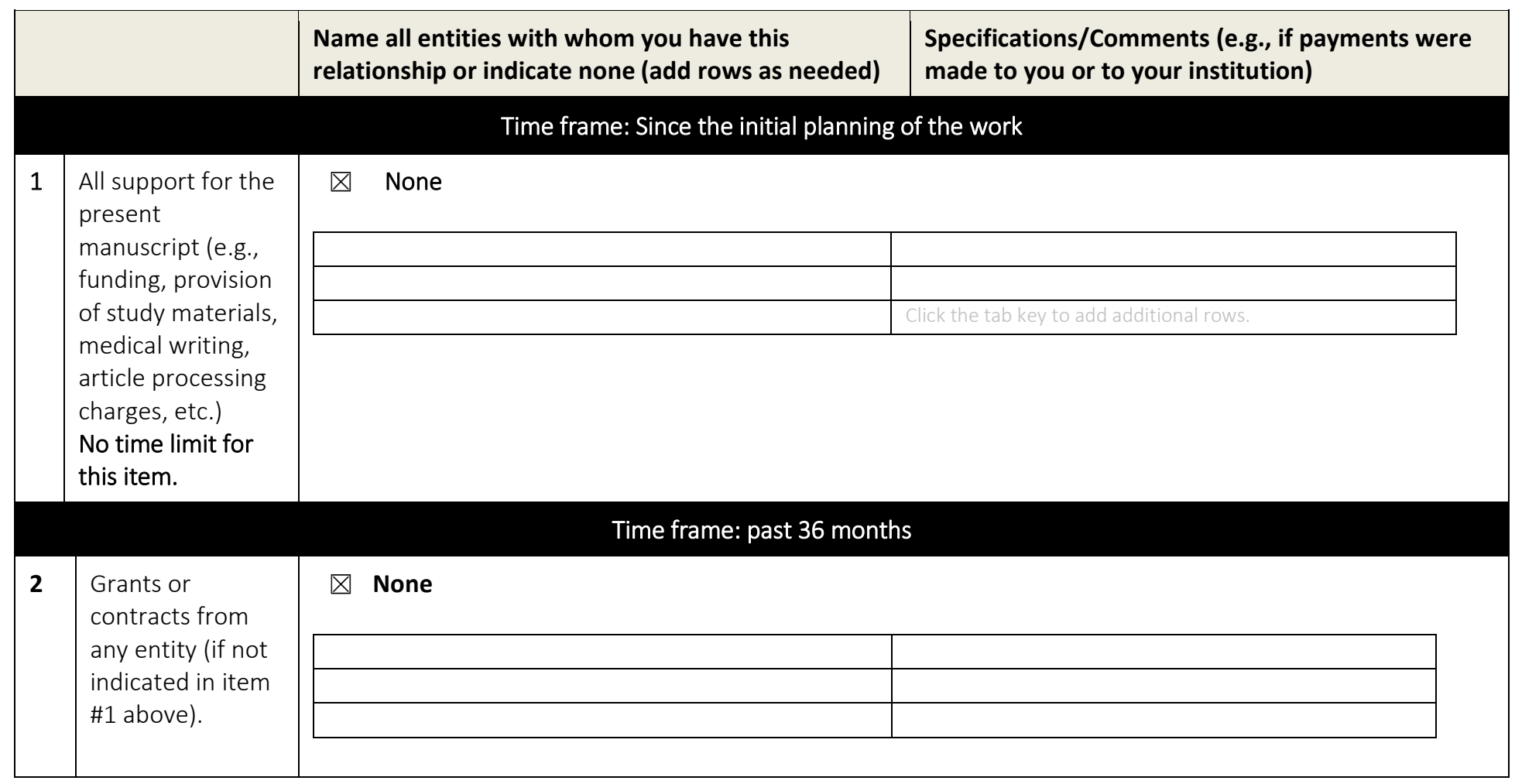


medRxiv preprint doi: https://doi.org/10.1101/2021.09.16.21263678; this version posted September 21, 2021. The copyright holder for this preprint (which was not certified by peer review) is the author/funder, who has granted medRxiv a license to display the preprint in perpetuity.

It is made available under a CC-BY-NC-ND 4.0 International license .

$3 \quad$ Royalties or licenses

Name all entities with whom you have this relationship or indicate none (add rows as needed)

Specifications/Comments (e.g., if payments were made to you or to your institution)

\section{$\bigotimes \quad$ None}

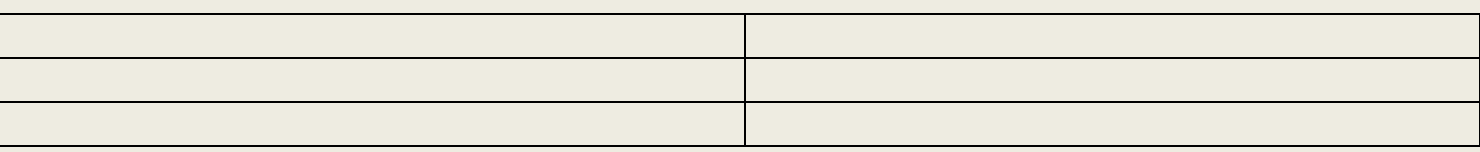

$4 \quad$ Consulting fees

$\otimes \quad$ None

5

Payment or

honoraria for

lectures,

presentations,

speakers

bureaus,

manuscript

writing or

educational

events

6 Payment for expert testimony

\section{$\bigotimes \quad$ None}

\section{$\otimes \quad$ None}

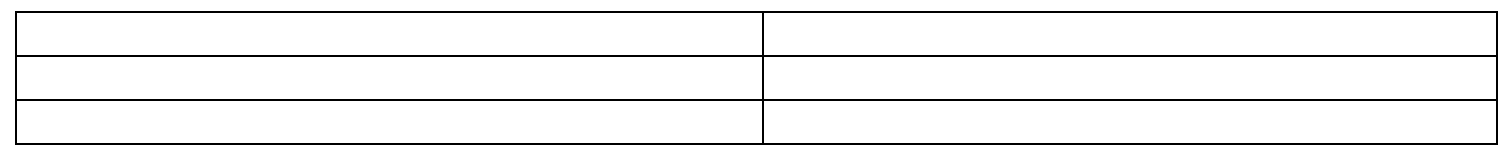

7 Support for attending meetings and/or travel issued or pending

\section{$\bigotimes \quad$ None}

\section{$\bigotimes \quad$ None}

\section{\None}

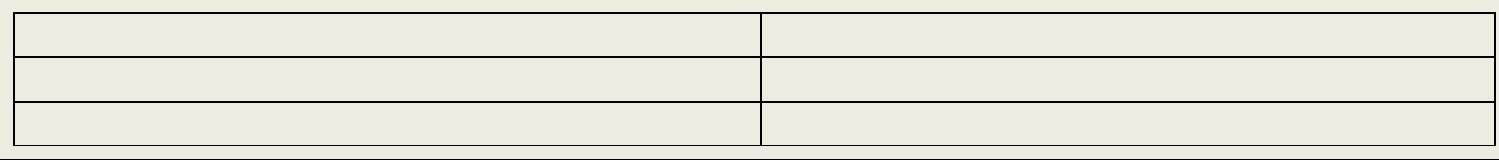

10 Leadership or fiduciary role in other board,

\section{叉 None}

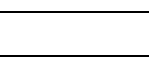


medRxiv preprint doi: https://doi.org/10.1101/2021.09.16.21263678; this version posted September 21, 2021. The copyright holder for this preprint (which was not certified by peer review) is the author/funder, who has granted medRxiv a license to display the preprint in perpetuity.

It is made available under a CC-BY-NC-ND 4.0 International license .

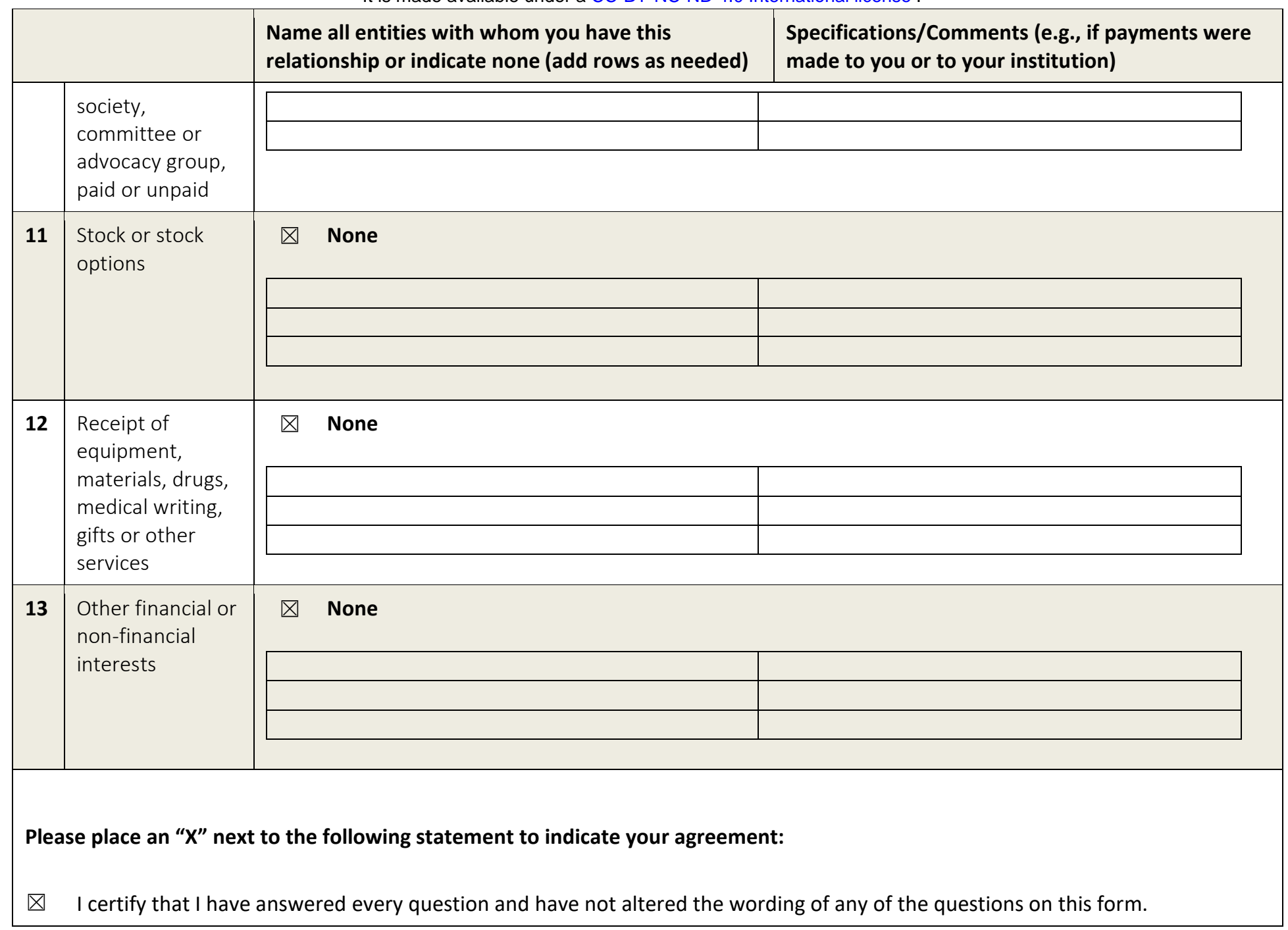




\section{Preferred Reporting Items for Systematic reviews and Meta-Analyses extension for Scoping Reviews (PRISMA-ScR) Checklist}

\begin{tabular}{|c|c|c|c|}
\hline SECTION & ITEM & PRISMA-ScR CHECKLIST ITEM & $\begin{array}{l}\text { REPORTED } \\
\text { ON PAGE \# }\end{array}$ \\
\hline \multicolumn{4}{|l|}{ TITLE } \\
\hline Title & 1 & Identify the report as a scoping review. & 1 \\
\hline \multicolumn{4}{|l|}{ ABSTRACT } \\
\hline $\begin{array}{l}\text { Structured } \\
\text { summary }\end{array}$ & 2 & $\begin{array}{l}\text { Provide a structured summary that includes (as } \\
\text { applicable): background, objectives, eligibility criteria, } \\
\text { sources of evidence, charting methods, results, and } \\
\text { conclusions that relate to the review questions and } \\
\text { objectives. }\end{array}$ & $1-2$ \\
\hline \multicolumn{4}{|l|}{ INTRODUCTION } \\
\hline Rationale & 3 & $\begin{array}{l}\text { Describe the rationale for the review in the context of } \\
\text { what is already known. Explain why the review } \\
\text { questions/objectives lend themselves to a scoping } \\
\text { review approach. }\end{array}$ & $2-3$ \\
\hline Objectives & 4 & $\begin{array}{l}\text { Provide an explicit statement of the questions and } \\
\text { objectives being addressed with reference to their key } \\
\text { elements (e.g., population or participants, concepts, and } \\
\text { context) or other relevant key elements used to } \\
\text { conceptualize the review questions and/or objectives. }\end{array}$ & $3-4$ \\
\hline \multicolumn{4}{|c|}{ 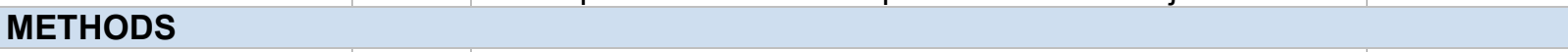 } \\
\hline $\begin{array}{l}\text { Protocol and } \\
\text { registration }\end{array}$ & 5 & $\begin{array}{l}\text { Indicate whether a review protocol exists; state if and } \\
\text { where it can be accessed (e.g., a Web address); and if } \\
\text { available, provide registration information, including the } \\
\text { registration number. }\end{array}$ & -4 \\
\hline Eligibility criteria & 6 & $\begin{array}{l}\text { Specify characteristics of the sources of evidence used } \\
\text { as eligibility criteria (e.g., years considered, language, } \\
\text { and publication status), and provide a rationale. }\end{array}$ & 5 \\
\hline $\begin{array}{l}\text { Information } \\
\text { sources* }^{*}\end{array}$ & 7 & $\begin{array}{l}\text { Describe all information sources in the search (e.g., } \\
\text { databases with dates of coverage and contact with } \\
\text { authors to identify additional sources), as well as the } \\
\text { date the most recent search was executed. }\end{array}$ & 4 \\
\hline Search & 8 & $\begin{array}{l}\text { Present the full electronic search strategy for at least } 1 \\
\text { database, including any limits used, such that it could be } \\
\text { repeated. }\end{array}$ & $4-5$ \\
\hline $\begin{array}{l}\text { Selection of } \\
\text { sources of } \\
\text { evidence } \dagger\end{array}$ & 9 & $\begin{array}{l}\text { State the process for selecting sources of evidence (i.e., } \\
\text { screening and eligibility) included in the scoping review. }\end{array}$ & 5 \\
\hline $\begin{array}{l}\text { Data charting } \\
\text { process } \ddagger\end{array}$ & 10 & $\begin{array}{l}\text { Describe the methods of charting data from the included } \\
\text { sources of evidence (e.g., calibrated forms or forms that } \\
\text { have been tested by the team before their use, and } \\
\text { whether data charting was done independently or in } \\
\text { duplicate) and any processes for obtaining and } \\
\text { confirming data from investigators. }\end{array}$ & 6 \\
\hline Data items & 11 & $\begin{array}{l}\text { List and define all variables for which data were sought } \\
\text { and any assumptions and simplifications made. }\end{array}$ & $5-6$ \\
\hline $\begin{array}{l}\text { Critical appraisal of } \\
\text { individual sources } \\
\text { of evidence }\end{array}$ & 12 & $\begin{array}{l}\text { If done, provide a rationale for conducting a critical } \\
\text { appraisal of included sources of evidence; describe the } \\
\text { methods used and how this information was used in any } \\
\text { data synthesis (if appropriate). }\end{array}$ & - \\
\hline Synthesis of results & 13 & $\begin{array}{l}\text { Describe the methods of handling and summarizing the } \\
\text { data that were charted. }\end{array}$ & $7-8$ \\
\hline
\end{tabular}




\begin{tabular}{|c|c|c|c|}
\hline SECTION & ITEM & PRISMA-ScR CHECKLIST ITEM & $\begin{array}{l}\text { REPORTED } \\
\text { ON PAGE \# }\end{array}$ \\
\hline \multicolumn{4}{|l|}{ RESULTS } \\
\hline $\begin{array}{l}\text { Selection of } \\
\text { sources of } \\
\text { evidence }\end{array}$ & 14 & $\begin{array}{l}\text { Give numbers of sources of evidence screened, } \\
\text { assessed for eligibility, and included in the review, with } \\
\text { reasons for exclusions at each stage, ideally using a flow } \\
\text { diagram. }\end{array}$ & 7 \\
\hline $\begin{array}{l}\text { Characteristics of } \\
\text { sources of } \\
\text { evidence }\end{array}$ & 15 & $\begin{array}{l}\text { For each source of evidence, present characteristics for } \\
\text { which data were charted and provide the citations. }\end{array}$ & 7 \\
\hline $\begin{array}{l}\text { Critical appraisal } \\
\text { within sources of } \\
\text { evidence }\end{array}$ & 16 & $\begin{array}{l}\text { If done, present data on critical appraisal of included } \\
\text { sources of evidence (see item 12). }\end{array}$ & - \\
\hline $\begin{array}{l}\text { Results of } \\
\text { individual sources } \\
\text { of evidence }\end{array}$ & 17 & $\begin{array}{l}\text { For each included source of evidence, present the } \\
\text { relevant data that were charted that relate to the review } \\
\text { questions and objectives. }\end{array}$ & 8 \\
\hline Synthesis of results & 18 & $\begin{array}{l}\text { Summarize and/or present the charting results as they } \\
\text { relate to the review questions and objectives. }\end{array}$ & 9 \\
\hline \multicolumn{4}{|l|}{ DISCUSSION } \\
\hline $\begin{array}{l}\text { Summary of } \\
\text { evidence }\end{array}$ & 19 & $\begin{array}{l}\text { Summarize the main results (including an overview of } \\
\text { concepts, themes, and types of evidence available), link } \\
\text { to the review questions and objectives, and consider the } \\
\text { relevance to key groups. }\end{array}$ & $10-11-12$ \\
\hline Limitations & 20 & Discuss the limitations of the scoping review process. & 13 \\
\hline Conclusions & 21 & $\begin{array}{l}\text { Provide a general interpretation of the results with } \\
\text { respect to the review questions and objectives, as well } \\
\text { as potential implications and/or next steps. }\end{array}$ & 14 \\
\hline \multicolumn{4}{|l|}{ FUNDING } \\
\hline Funding & 22 & $\begin{array}{l}\text { Describe sources of funding for the included sources of } \\
\text { evidence, as well as sources of funding for the scoping } \\
\text { review. Describe the role of the funders of the scoping } \\
\text { review. }\end{array}$ & 14 \\
\hline \multicolumn{4}{|c|}{$\begin{array}{l}\text { JBI = Joanna Briggs Institute; PRISMA-ScR = Preferred Reporting Items for Systematic reviews and Meta-Analyses } \\
\text { extension for Scoping Reviews. } \\
\text { * Where sources of evidence (see second footnote) are compiled from, such as bibliographic databases, social media } \\
\text { platforms, and Web sites. } \\
\text { † A more inclusive/heterogeneous term used to account for the different types of evidence or data sources (e.g., } \\
\text { quantitative and/or qualitative research, expert opinion, and policy documents) that may be eligible in a scoping } \\
\text { review as opposed to only studies. This is not to be confused with information sources (see first footnote). } \\
\text { † The frameworks by Arksey and O'Malley (6) and Levac and colleagues }(7) \text { and the JBI guidance }(4,5) \text { refer to the } \\
\text { process of data extraction in a scoping review as data charting. } \\
\S \text { The process of systematically examining research evidence to assess its validity, results, and relevance before } \\
\text { using it to inform a decision. This term is used for items } 12 \text { and } 19 \text { instead of "risk of bias" (which is more applicable } \\
\text { to systematic reviews of interventions) to include and acknowledge the various sources of evidence that may be used } \\
\text { in a scoping review (e.g., quantitative and/or qualitative research, expert opinion, and policy document). }\end{array}$} \\
\hline
\end{tabular}

From: Tricco AC, Lillie E, Zarin W, O'Brien KK, Colquhoun H, Levac D, et al. PRISMA Extension for Scoping Reviews (PRISMAScR): Checklist and Explanation. Ann Intern Med. 2018;169:467-473. doi: 10.7326/M18-0850. 